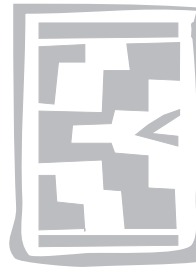

\title{
Birds as hosts of immature ixodid ticks in Free State Province, South Africa
}

\author{
D.J. VAN NIEKERK, L.J. FOURIE and I.G. HORAK \\ Department of Zoology and Entomology, University of the Free State \\ P.O. Box 339, Bloemfontein, 9300 South Africa
}

\begin{abstract}
VAN NIEKERK, D.J., FOURIE, L.J. \& HORAK, I.G. 2006. Birds as hosts of immature ixodid ticks in Free State Province, South Africa. Onderstepoort Journal of Veterinary Research, 73:123-130

The objective of this study was to determine the species spectrum of ixodid ticks infesting birds in Free State Province, South Africa. To this end a large number of birds belonging to several species were examined for ticks and a total of 180 birds belonging to 39 species at 17 localities were infested, and ticks belonging to eight species were recovered. The immature stages of only two, namely Amblyomma marmoreum and Hyalomma marginatum rufipes, were sufficiently prevalent and numerous to safely assume that they regularly use birds as hosts. Helmeted guineafowls, Numida meleagris, were the most heavily infested and one harboured a total of 319 larvae and four nymphs. Amongst the other species an eastern clapper lark, Mirafra fasciolata, was infested with 69 larvae and a nymph, but no other bird harboured more than 40 ticks. The larvae and nymphs of $\mathrm{H}$. m. rufipes were most numerous on birds from April to August
\end{abstract}

Keywords: Amblyomma marmoreum, birds, Hyalomma marginatum rufipes, ixodid ticks, seasonal occurrence

\section{INTRODUCTION}

Despite the small size of most birds their capacity for rapid and maintained population growth can contribute significantly to the demography of those tick species that use them as hosts. Certain species daily fly considerable distances, and may alight in diverse habitats during such flights, thus enhancing their potential for the acquisition, transport and dissemination of ticks. Furthermore, the seasonal migratory species cover considerable distances in a relatively short period of time and can therefore transport ticks from one country or even continent to another (Hoogstraal, Kaiser, Traylor, Gaber \& Guindy 1961).

Accepted for publication 28 March 2006-Editor
Few of the migratory birds examined in Egypt by Hoogstraal et al. (1961) were infested, and those that were, harboured only small numbers of ticks. In contrast, it would appear as if a large proportion of migratory and non-migratory ground-frequenting birds in rural and wildlife regions of South Africa are infested. The individual burdens of those species commonly referred to as game birds, namely guineafowls, spurfowls and francolins, may be large, often exceeding 100 and sometimes 1000 immature ticks (Horak, Spickett, Braack \& Williams 1991b; Uys \& Horak 2005).

In southern Africa, the adults of four tick species, Haemaphysalis hoodi, Ixodes pterodromae, Ixodes theilerae and Ixodes uriae prefer birds as hosts (Walker 1991). The adults of two other species, Hyalomma marginatum rufipes and Rhipicephalus 
turanicus, although they usually infest mammals, may infest ostriches, and those of the latter tick, also the larger raptors (Theiler 1962; Norval 1982; Walker, Keirans \& Horak 2000). Birds, however, serve as hosts of the immature stages of a number of tick species (Theiler 1962). Helmeted guineafowls, Numida meleagris, are good hosts of the immature stages of Amblyomma hebraeum, Amblyomma marmoreum, Haemaphysalis silacea, H. m. rufipes and Hyalomma glabrum (at the time referred to as Hyalomma marginatum turanicum) (Horak \& Williams 1986; Rechav, Zeederberg \& Zeller 1987; Horak et al. 1991b). Crested francolins, Dendroperdix sephaena, are good hosts of the immature stages of $A$. hebraeum, A. marmoreum and H. m. rufipes (Uys \& Horak 2005), and Cape francolins, Pternistis capensis, are hosts of the immature stages of Haemaphysalis aciculifer (Horak \& Boomker 1998). Birds of several other species may be infested with the larvae of $A$. marmoreum and the immature stages of $H$. m. rufipes and $H$. glabrum (H. m. turanicum) (Norval 1975; Norval 1982; Horak \& Boomker 1998; Horak, Fourie, Novellie \& Williams 1991a).

Because the adults of Hyalomma spp. are often the cause of lameness in small domestic stock (Kok \& Fourie 1995), and those of Ixodes rubicundus and Rhipicephalus warburtoni of toxin-induced paralysis in these animals (Fourie, Horak \& Marais 1988; Fourie, Petney, Horak \& De Jager 1989), a number of surveys to determine the host spectrum of these ticks in Free State Province, South Africa were conducted. Several birds were examined during these surveys, while other birds were examined for ticks when ringed by one of us (DJVN). This paper presents the findings of these investigations and discusses the role played by birds as hosts of the immature stages of ixodid ticks in South Africa.

\section{MATERIALS AND METHODS}

Ticks were collected from birds at various localities in Free State Province, South Africa (Table1). The names of the birds and the sequence in which they are listed follow Maclean (1993), and their common names are those recorded by Hockey, Dean \& Ryan (2005). Larger birds were processed for tick recovery as described by Horak \& Williams (1986) and smaller birds as described by Horak et al. (1991a). When live birds were ringed the head, neck, body, wings and tail were carefully examined with the naked eye and all visible ticks collected. Excluding the ticks from one of the helmeted guineafowls, which was particularly heavily infested, the mean monthly burdens of immature $H$. m. rufipes were calculated irrespective of the year in which the birds were examined.

\section{RESULTS AND DISCUSSION}

The species and numbers of birds examined and the species and numbers of ticks they harboured are summarized in Table 2. The immature stages of eight ixodid tick species were recovered from 180 birds belonging to 39 species. Larvae and nymphs of $H$. $m$. rufipes were the most numerous and prevalent, followed by the larvae of $A$. marmoreum. A single helmeted guineafowl in the Willem Pretorius Nature Reserve harboured the largest infestation of both species, with 209 larvae and a nymph of $A$. marmoreum and 106 larvae and three nymphs of $H$. $m$. rufipes. In addition it was also infested with three larvae of Rhipicephalus evertsi evertsi and a single larva of Rhipicephalus gertrudae. With the exception of an eastern clapper lark, Mirafra fasciolata, at Glen Agricultural College, which harboured 69 larvae and a nymph of $H$. m. rufipes, and four other birds that each harboured 20 or more larvae and nymphs, no bird was infested with more than 20 ticks.

\section{Amblyomma marmoreum}

Infestation with this tick was most prevalent on helmeted guineafowls in the Willem Pretorius Nature Reserve, and four of the six birds examined were infested. Fifteen smaller birds belonging to 11 species were also examined in this reserve, but not one was infested. Of the 170 birds, other than helmeted guineafowls, examined elsewhere in the province, 35 were infested and their individual burdens never exceeded five ticks.

Adult $A$. marmoreum, colloquially known as the South African tortoise tick, infests tortoises, and more particularly the leopard tortoise, Geochelone pardalis as hosts (Horak, McKay, Heyne \& Spickett 2006). The immature stages infest tortoises, some of the larger reptiles, a large number of bird species, hares, antelopes, carnivores and domestic livestock (Norval 1975; Horak \& Fourie 1991; Horak et al. 1991a; 2006; Horak, Braack, Fourie \& Walker 2000). Helmeted guineafowls appear to be good hosts of the larvae of this tick. In previous surveys several of them harboured more than 50 larvae with 585 being the largest number recovered. However, the number of nymphs rarely exceeded five (Horak \& Williams 1986; Horak et al. 1991b). Thirteen of 16 helmeted guineafowls examined in an earlier study in the Mountain Zebra National Park, Eastern Cape Prov- 
TABLE 1 Localities in Free State Province at which ticks were collected from birds

\begin{tabular}{|c|c|c|}
\hline Tick species & Locality & Coordinates \\
\hline Amblyomma marmoreum & $\begin{array}{l}\text { Bishop's Glen* } \\
\text { Salopia* } \\
\text { Slangfontein* } \\
\text { Wolwespruit* }^{*}\end{array}$ & $\begin{array}{l}29^{\circ} 00^{\prime} \mathrm{S} ; 26^{\circ} 21^{\prime} \mathrm{E} \\
29^{\circ} 12^{\prime} \mathrm{S} ; 25^{\circ} 58^{\prime} \mathrm{E} \\
30^{\circ} 08^{\prime} \mathrm{S} ; 25^{\circ} 24^{\prime} \mathrm{E} \\
28^{\circ} 51^{\prime} \mathrm{S} ; 25^{\circ} 32^{\prime} \mathrm{E}\end{array}$ \\
\hline $\begin{array}{l}\text { Amblyomma marmoreum and } \\
\text { Hyalomma marginatum rufipes }\end{array}$ & $\begin{array}{l}\text { Willem Pretorius NR } \\
\text { Glen Agricultural College } \\
\text { Preezfontein* } \\
\text { Doornhoek* }^{*}\end{array}$ & $\begin{array}{l}28^{\circ} 18^{\prime} \mathrm{S} ; 27^{\circ} 15^{\prime} \mathrm{E} \\
28^{\circ} 54^{\prime} \mathrm{S} ; 26^{\circ} 21^{\prime}, \mathrm{E} \\
29^{\circ} 50^{\prime} \mathrm{S} ; 25^{\circ} 23^{\prime} \mathrm{E} \\
28^{\circ} 53^{\prime} \mathrm{S} ; 25^{\circ} 43^{\prime} \mathrm{E}\end{array}$ \\
\hline Hyalomma marginatum rufipes & $\begin{array}{l}\text { Bloemfontein } \\
\text { Morning Star* }^{\star} \\
\text { Floradale* }^{*} \\
\text { Sandveld NR } \\
\text { Wolwekop }^{\star} \\
\text { Nooitgedacht }^{\star} \\
\text { Ventersvlei }^{*} \\
\text { Soetdoring NR }\end{array}$ & $\begin{array}{l}29^{\circ} 08^{\prime} \mathrm{S} ; 26^{\circ} 10^{\prime} \mathrm{E} \\
28^{\circ} 48^{\prime} \mathrm{S} ; 27^{\circ} 14^{\prime} \mathrm{E} \\
28^{\circ} 57^{\prime} \mathrm{S} ; 26^{\circ} 13^{\prime} \mathrm{E} \\
27^{\circ} 38^{\prime} \mathrm{S} ; 25^{\circ} 42^{\prime} \mathrm{E} \\
29^{\circ} 27^{\prime} \mathrm{S} ; 26^{\circ} 40^{\prime} \mathrm{E} \\
29^{\circ} 13^{\prime} \mathrm{S} ; 25^{\circ} 54^{\prime} \mathrm{E} \\
29^{\circ} 14^{\prime} \mathrm{S} ; 25^{\circ} 55^{\prime} \mathrm{E} \\
28^{\circ} 50^{\prime} \mathrm{S} ; 26^{\circ} 04^{\prime} \mathrm{E}\end{array}$ \\
\hline Hyalomma glabrum & Tussen-die-Riviere NR & $30^{\circ} 29^{\prime} \mathrm{S} ; 2^{\circ} 15^{\prime} \mathrm{E}$ \\
\hline Haemaphysalis leachi & Tussen-die-Riviere NR & $30^{\circ} 29^{\prime} \mathrm{S} ; 2^{\circ} 15^{\prime} \mathrm{E}$ \\
\hline Ixodes rubicundus & $\begin{array}{l}\text { Bishop's Glen* } \\
\text { Tussen-die-Riviere NR } \\
\text { Slangfontein* }\end{array}$ & $\begin{array}{l}29^{\circ} 00^{\prime} \text { S; } 26^{\circ} 21^{\prime} \mathrm{E} \\
30^{\circ} 29^{\prime} \mathrm{S} ; 26^{\circ} 15^{\prime} \mathrm{E} \\
30^{\circ} 08^{\prime} \text { S; } 25^{\circ} 24^{\prime} \mathrm{E}\end{array}$ \\
\hline Rhipicephalus evertsi evertsi & Willem Pretorius NR & $28^{\circ} 18^{\prime} \mathrm{S} ; 2^{\circ} 15^{\prime} \mathrm{E}$ \\
\hline Rhipicephalus gertrudae & $\begin{array}{l}\text { Tussen-die-Riviere NR } \\
\text { Willem Pretorius NR }\end{array}$ & $\begin{array}{l}30^{\circ} 29^{\prime} \mathrm{S} ; 26^{\circ} 15^{\prime} \mathrm{E} \\
28^{\circ} 18^{\prime} \mathrm{S} ; 27^{\circ} 15^{\prime} \mathrm{E}\end{array}$ \\
\hline Rhipicephalus warburtoni & Slangfontein* & $30^{\circ} 08^{\prime} \mathrm{S} ; 2^{\circ} 24^{\prime} \mathrm{E}$ \\
\hline
\end{tabular}

ince were infested, but not one of 27 smaller birds belonging to five other species (Horak et al. 1991a). Other game birds that are regularly infested, and of which individuals may harbour large burdens, are francolins and spurfowls (Horak \& Boomker 1998; Uys \& Horak 2005).

Smaller birds are either less exposed to the larvae of $A$. marmoreum because of their size, or because they spend less time on the ground, or they may be less susceptible. The larvae of this tick quest for hosts from the vegetation (Horak et al. 2006), whereas the activity of many of the smaller birds is confined to the soil surface and hence they may not even come into contact with the larvae. Few nymphs are collected from the vegetation by sampling with flannel strips (Spickett, Horak, Van Niekerk \& Braack 1992; Horak et al. 2006), indicating that they probably quest for hosts from the soil surface. This may explain the larger number of nymphs collected from small birds than from helmeted guineafowls (Table 2).
Larvae are generally most numerous on the vegetation from late summer to midwinter, and nymphs from spring to midsummer (Norval 1975; Rechav et al. 1987; Spickett et al. 1992; Horak et al. 2006). The presence of this tick on birds could thus also be expected to be seasonal, but because too few ticks were collected from too few birds this could not be verified.

\section{Hyalomma species}

Three tick species belonging to the genus Hyalomma, namely $H$. truncatum, $H$. m. rufipes and $H$. glabrum (H. m. turanicum) are present in South Africa (Walker 1991). Both $H$. truncatum and $H$. m. rufipes are widespread and there is considerable overlap in their distributions (Howell, Walker \& Nevill 1978). Hyalomma glabrum, which until recently was considered to be identical to Asian Hyalomma marginatum turanicum (Apanaskevich \& Horak 2006), has a more restricted distribution (Howell et al. 1978), and the only region of Free State Province in which there is substantial 
TABLE 2 Ixodid ticks collected from birds in Free State Province, South Africa. Bird names and sequence according to Maclean (1993) and Hockey et al. (2005)

\begin{tabular}{|c|c|c|c|c|c|c|c|}
\hline \multicolumn{2}{|l|}{ Bird } & \multirow{3}{*}{$\begin{array}{l}\text { Number } \\
\text { infested }\end{array}$} & \multicolumn{4}{|c|}{ Number of ticks collected } & \multirow{3}{*}{ Other tick species } \\
\hline \multirow{2}{*}{ Common name } & \multirow{2}{*}{ Scientific name } & & \multicolumn{2}{|c|}{ Amblyomma marmoreum } & \multicolumn{2}{|c|}{ Hyalomma marginatum rufipes } & \\
\hline & & & Larvae & Nymphs & Larvae & Nymphs & \\
\hline Cattle Egret & Bubulcus ibis & 1 & & & & & H. m. rufipes 1 male \\
\hline Orange River Francolin & Scleroptila levaillantoides & 1 & & & 8 & & \\
\hline Swainson's Spurfowl & Pternistis swainsonii & 1 & & & 1 & 1 & \\
\hline Helmeted Guineafowl & Numida meleagris & 10 & 233 & 3 & 139 & 6 & $\begin{array}{l}\text { H. glabrum } 12 \mathrm{LL}, 4 \mathrm{NN} \text {; } R \text {. e. } \\
\text { evertsi } 4 \mathrm{LL} ; \text { R. gertrudae } 2 \mathrm{LL}\end{array}$ \\
\hline Northern Black Korhaan & Afrotis afraoides & 3 & & & 2 & 5 & \\
\hline Caspian Plover & Charadrius asiaticus & 1 & & & 1 & 2 & \\
\hline Crowned Lapwing & Vanellus coronatus & 3 & & & 15 & 14 & \\
\hline Double-banded Courser & Rhinoptilus africanus & 1 & & & & 1 & \\
\hline Namaqua Dove & Oena capensis & 1 & & & 1 & & \\
\hline Spotted Eagle Owl & Bubo africanus & 1 & & & 14 & 10 & \\
\hline Rufous-cheeked Nightjar & Caprimulgus rufigena & 5 & & 2 & 1 & 4 & \\
\hline Melodious Lark & Mirafra cheniana & 6 & 1 & 1 & 8 & 13 & \\
\hline Eastern Clapper Lark & Mirafra fasciolata & 22 & 2 & 8 & 108 & 8 & \\
\hline Spike-heeled Lark & Chersomanes albofasciata & 34 & 7 & 2 & 93 & 7 & $\begin{array}{l}\text { I. rubicundus } 3 \mathrm{LL} ; \\
\text { R. warburtoni } 5 \mathrm{LL}, 15 \mathrm{NN}\end{array}$ \\
\hline Red-capped Lark & Calandrella cinerea & 1 & & & 1 & & \\
\hline Pink-billed Lark & Spizocorys conirostris & 1 & & & 2 & 2 & \\
\hline Large-billed Lark & Galerida magnirostris & 5 & 12 & & 1 & 1 & \\
\hline Ashy Tit & Parus cinerascens & 1 & & & & 6 & \\
\hline African Red-eyed Bulbul & Pycnonotus nigricans & 2 & & & 1 & 1 & R. gertrudae $1 \mathrm{LL}$ \\
\hline Ant-eating Chat & Myrmecocichla formicivora & 5 & & & 6 & 2 & H. leachi $1 \mathrm{~N}$ \\
\hline Cape Robin-Chat & Cossypha caffra & 4 & & 2 & 5 & 12 & \\
\hline Karoo Scrub-Robin & Cercotrichas coryphoeus & 7 & 2 & & 15 & 32 & R. gertrudae $1 \mathrm{LL}$ \\
\hline Kalahari Scrub-Robin & Cercotrichas paena & 1 & & 1 & & & \\
\hline
\end{tabular}


TABLE 2 cont.

\begin{tabular}{|c|c|c|c|c|c|c|c|}
\hline \multicolumn{2}{|l|}{ Bird } & \multirow{3}{*}{$\begin{array}{l}\text { Number } \\
\text { infested }\end{array}$} & \multicolumn{4}{|c|}{ Number of ticks collected } & \multirow{3}{*}{ Other tick species } \\
\hline \multirow{2}{*}{ Common name } & \multirow{2}{*}{ Scientific name } & & \multicolumn{2}{|c|}{ Amblyomma marmoreum } & \multicolumn{2}{|c|}{ Hyalomma marginatum rufipes } & \\
\hline & & & Larvae & Nymphs & Larvae & Nymphs & \\
\hline Chestnut-vented Tit-babbler & Parisoma subcaeruleum & 2 & & & 1 & 1 & \\
\hline Desert Cisticola & Cisticola aridulus & 1 & & & 2 & & \\
\hline Cloud Cisticola & Cisticola textrix & 5 & & 1 & 6 & 1 & \\
\hline Blackchested Prinia & Prinia flavicans & 2 & 2 & & & 1 & \\
\hline Marico Flycatcher & Bradornis mariquensis & 1 & & & & 2 & \\
\hline Fiscal Flycatcher & Sigelus silens & 3 & & & 2 & 7 & \\
\hline Pririt Batis & Batis pririt & 1 & 2 & & & & \\
\hline Cape Wagtail & Motacilla capensis & 1 & & & & 1 & \\
\hline African Pipit & Anthus cinnamomeus & 2 & & & 3 & & \\
\hline Pipit & Anthus sp. & 2 & 1 & & 6 & 4 & \\
\hline Bokmakierie & Telophorus zeylonus & 1 & & & 3 & 1 & \\
\hline Pied Starling & Spreo bicolor & 4 & & & 8 & 2 & \\
\hline Wattled Starling & Creatophora cinerea & 31 & & & 59 & 29 & \\
\hline Cape Weaver & Ploceus capensis & 1 & & & & & I. rubicundus $2 \mathrm{LL}$ \\
\hline Red Bishop & Euplectes orix & 5 & & & 3 & 5 & I. rubicundus 1 female \\
\hline Bunting & Emberiza sp. & 1 & 1 & & & & \\
\hline \multicolumn{2}{|l|}{ Totals } & 180 & 263 & 20 & 515 & 181 & \\
\hline
\end{tabular}

$\mathrm{LL}=$ larvae

$\mathrm{NN}=$ nymphs 
overlap in the geographic distribution of this tick and that of $H$. m. rufipes is the south-west (Howell et al. 1978).

These are all two-host ticks and the immature stages of $H$. truncatum and $H$. $m$. rufipes can readily be differentiated from each other (Arthur 1975a; b), whereas those of the latter tick and $\mathrm{H}$. glabrum are somewhat similar in appearance (Apanaskevich \& Horak 2006). The only birds examined in the south-west region of the Free State Province were those on the farms "Slangfontein" and "Preezfontein" and in the Tussen-die-Riviere Nature Reserve. Helmeted guineafowls in the reserve were infested with larvae and nymphs of $H$. glabrum (Table 2).

Hyalomma m. rufipes was the most numerous of the ticks recovered and the majority of bird species examined in Free State Province were infested. It was also the most numerous tick collected by Hoogstraal et al. (1961) from birds migrating from East Africa to Europe and to Asia via Egypt. All but seven of the 1025 immature ticks they collected from 340 birds belonged to this species. In the present survey seven of ten helmeted guineafowls examined were infested and one of these birds harboured the highest individual total for a bird of any species, namely 106 larvae and three nymphs. Helmeted guineafowls are not only the largest birds examined in the present survey, but they also spend most of the day on the ground, making them readily accessible to the larvae of $H$. $m$. rufipes. The bare heads and upper necks of these birds are a favoured attachment site for larvae of several tick species (Horak \& Williams 1986), and probably also for those of $H$. m. rufipes. Although the heads and upper necks of crested francolins, $D$. sephanea are not bare, more than $90 \%$ of $H$. m. rufipes larvae have been recovered from here on these birds (Uys \& Horak 2005).

The overall ratio of $515 \mathrm{H}$. m. rufipes larvae to 181 nymphs on birds implies a satisfactory translation of one developmental stage to the next and that birds are thus suitable hosts of the tick.

The adults of $H$. m. rufipes attach to large animals such as African buffaloes, Syncerus caffer, eland, Taurotragus oryx, giraffes, Giraffa camelopardalis and domestic cattle (Norval 1982; Rechav et al. 1987; Horak, Swanepoel \& Gummow 2002). They are most numerous on these animals during the summer months (Londt, Horak \& de Villiers 1979; Rechav et al. 1987; Fourie, Kok \& Heyne 1996; Dreyer, Fourie \& Kok 1998). The immature stages use birds, Cape hares, Lepus capensis and scrub hares, Lepus saxatilis as hosts (Norval 1982; Rechav et al. 1987;

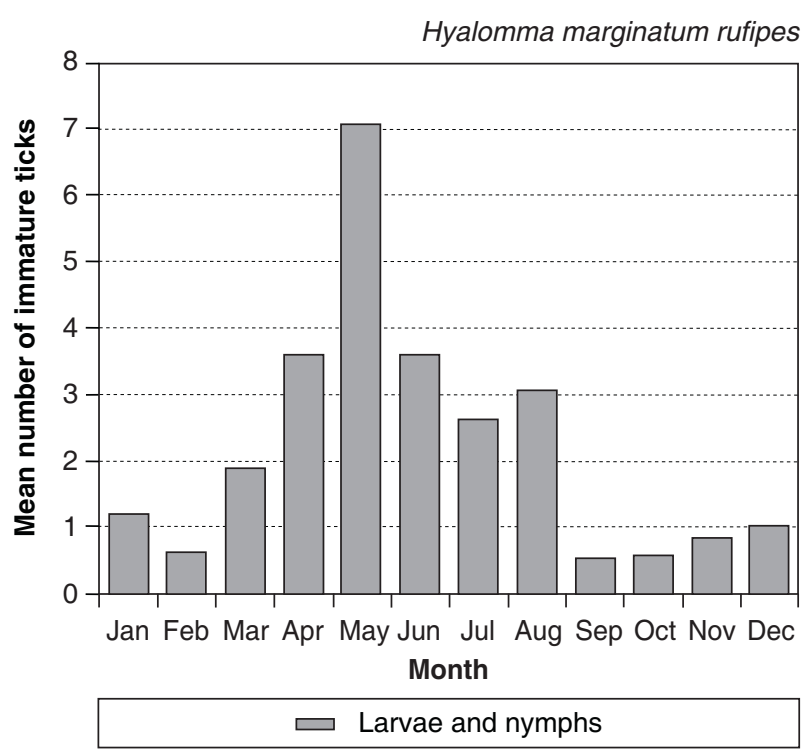

FIG. 1 Seasonal occurrence of the immature stages of Hyalomma marginatum rufipes on birds in Free State Province, South Africa

Horak \& Fourie 1991), and are most numerous on helmeted guineafowls and hares from late summer to late winter (Rechav et al. 1987; Horak \& Fourie 1991). In the present survey most immature ticks were collected from birds between April and August with a peak in May (Fig. 1). The discrete separate periods of seasonal occurrence of the adults and the immature stages imply that a single life cycle is completed annually.

Hyalomma $m$. rufipes is probably the principal vector in South Africa of the virus causing Crimean Congo haemorrhagic fever (Horak et al. 2002; Swanepoel \& Burt 2004). Although certain bird species would seem to be susceptible to experimental infection with the virus and can then transmit it to $H$. m. rufipes (Zeller, Cornet \& Camicas 1994), according to Swanepoel \& Burt (2004) it seems unlikely that this would occur naturally. The larvae and nymphs require 22 days to complete feeding on experimentally infested rabbits (Knight, Norval \& Rechav 1978), and if they require the same length of time to feed on birds, their long-distance translocation is a distinct possibility, particularly on migratory species.

The hosts and seasonal occurrence of adult and immature $H$. glabrum [at the time considered to be $H$. $m$. turanicum by Horak et al. (1991a)] are similar to those of $H$. $m$. rufipes. Its host spectrum is, however, curtailed by the limits of its own distribution in South Africa. The immature stages of $H$. truncatum infest scrub hares and rodents (Horak et al. 1991a). If they are found on birds it can safely be assumed that they 
are 'stragglers' from a heavily contaminated environment.

\section{Other ticks}

The remaining five tick species must be considered 'stragglers' and their presence on the birds reflecting local or seasonal abundance rather than host preference. The immature stages of Haemaphysalis leachi and $R$. gertrudae parasitize murid rodents (Norval 1984; Walker et al. 2000), and those of $I$. rubicundus and $R$. warburtoni parasitize rock elephant shrews, Elephantulus myurus (Fourie, Horak \& Van Den Heever 1992; Walker et al. 2000). However, an engorged female I. rubicundus was recovered from a red bishop, Euplectes orix. The immature stages of $R$. e. evertsi prefer domestic and wild equids as hosts, but may also be found on a large variety of other animals, and occasionally also on birds (Walker et al. 2000).

\section{ACKNOWLEDGEMENTS}

We are most grateful to the farmers, landowners and nature reserve managers and the management of Glen Agricultural College for permission to collect birds and ticks on the properties under their authority. Mr E. J. Williams was responsible for the collection of ticks from many of the birds and Dr G. Kopij for those from the starlings at Bloemfontein and Excelsior.

\section{REFERENCES}

APANASKEVICH, D.A. \& HORAK, I.G. 2006. The genus Hyalomma Koch, 1844. I. Reinstatement of Hyalomma (Euhyalomma) glabrum Delpy, 1949 (Acari, Ixodidae) as a valid species with a re-description of the adults, first description of the immature stages and notes on its biology. Onderstepoort Journal of Veterinary Research, 73:1-12.

ARTHUR, D.R. 1975a. The larvae of some ixodid ticks (Acarina) from the eastern Cape Province of South Africa. Bulletin of Entomological Research, 65:405-421.

ARTHUR, D.R. 1975b. The nymphs of some ixodid ticks (Acarina) from the eastern Cape Province of South Africa. Bulletin of Entomological Research, 65: 423-431.

DREYER, KARIN, FOURIE, L.J. \& KOK, D.J. 1998. Tick diversity, abundance and seasonal dynamics in a resource-poor urban environment in the Free State Province. Onderstepoort Journal of Veterinary Research, 65:305-316.

FOURIE, L.J., HORAK, I.G. \& MARAIS, L. 1988. An undescribed Rhipicephalus species associated with field paralysis of Angora goats. Journal of the South African Veterinary Association, 59:47-49.

FOURIE, L.J., PETNEY, T.N., HORAK, I.G. \& DE JAGER, C. 1989. Seasonal incidence of Karoo paralysis in relation to the infestation density of female Ixodes rubicundus. Veterinary Parasitology, 33:319-328.
FOURIE, L.J., HORAK, I.G. \& VAN DEN HEEVER, J.J. 1992. The relative host status of rock elephant shrews Elephantulus myurus and Namaqua rock mice Aethomys namaquensis for economically important ticks. South African Journal of Zoology, 27:108-114.

FOURIE, L.J., KOK, D.J. \& HEYNE, H. 1996. Adult ixodid ticks on two cattle breeds in the south-western Free State, and their seasonal dynamics. Onderstepoort Journal of Veterinary Research, 63:19-23.

HOCKEY, P.A.R., DEAN, W.J.R. \& RYAN, P.G. (Eds) 2005. Roberts' Birds of Southern Africa. Cape Town: The Trustees of the John Voelcker Bird Book Fund.

HOOGSTRAAL, H., KAISER, M.N., TRAYLOR, M.A., GABER, S. \& GUINDY, E. 1961. Ticks (Ixodoidea) on birds migrating from Africa to Europe and Asia. Bulletin of the World Health Organisation, 24:197-212.

HORAK, I.G. \& WILLIAMS, E.J. 1986. Parasites of domestic and wild animals in South Africa. XVIII. The crowned guinea fowl (Numida meleagris), an important host of immature ixodid ticks. Onderstepoort Journal of Veterinary Research, 53:119122.

HORAK, I.G., FOURIE, L.J., NOVELLIE, P.A. \& WILLIAMS, E.J. 1991a. Parasites of domestic and wild animals in South Africa. XXVI. The mosaic of ixodid tick infestations on birds and mammals in the Mountain Zebra National Park. Onderstepoort Journal of Veterinary Research, 58:125-136.

HORAK, I.G., SPICKETT, A.M., BRAACK, L.E.O. \& WILLIAMS, E.J. 1991b. Parasites of domestic and wild animals in South Africa. XXVII. Ticks on helmeted guineafowls in the eastern Cape Provinceandeastern Transvaal Lowveld. Onderstepoort Journal of Veterinary Research, 58:137-143.

HORAK, I.G. \& FOURIE, L.J. 1991. Parasites of domestic and wild animals in South Africa. XXIX. Ixodid ticks on hares in the Cape Province and on hares and red rock rabbits in the Orange Free State. Onderstepoort Journal of Veterinary Research, 58:261-270.

HORAK, I.G. \& BOOMKER, J. 1998. Parasites of domestic and wild animals in South Africa. XXXV. Ixodid ticks and bot fly larvae in the Bontebok National Park. Onderstepoort Journal of Veterinary Research, 65:205-211.

HORAK, I.G., BRAACK, L.E.O., FOURIE, L.J. \& WALKER, JANE B. 2000. Parasites of domestic and wild animals in South Africa. XXXVIII. Ixodid ticks collected from 23 wild carnivore species. Onderstepoort Journal of Veterinary Research, 67: 239-250.

HORAK, I.G., SWANEPOEL, R. \& GUMMOW, B. 2002. The distribution of Hyalomma spp. and human cases of CrimeanCongo haemorrhagic fever in South Africa. In: Proceedings of the $10^{\text {th }}$ Conference of the Association of Institutions for Tropical Veterinary Medicine, Copenhagen, Denmark, 20-23 August 2001: 501-509.

HORAK, I.G., MCKAY, I.J., HEYNE, HELOISE \& SPICKETT, A. M. 2006. Hosts, seasonality and geographic distribution of the South African tortoise tick, Amblyomma marmoreum. Onderstepoort Journal of Veterinary Research, 73:13-25.

HOWELL, C.J., WALKER, JANE B. \& NEVILL, E.M. 1978. Ticks, mites and insects infesting domestic animals in South Africa. Part 1. Descriptions and biology. Pretoria: Department of Agricultural Technical Services, Republic of South Africa. (Science Bulletin no. 393).

KNIGHT, M.M., NORVAL, R.A.I. \& RECHAV, Y. 1978. The life cycle of the tick Hyalomma marginatum rufipes Koch (Acarina: Ixodidae) under laboratory conditions. Journal of Parasitology, 64:143-146. 
KOK, D.J. \& FOURIE, L.J. 1995. The role of Hyalomma ticks in foot infestations and temporary lameness of sheep in a semiarid region of South Africa. Onderstepoort Journal of Veterinary Research, 62:201-206.

LONDT, J.G.H., HORAK, I.G. \& DE VILLIERS, I.L. 1979. Parasites of domestic and wild animals in South Africa. XIII. The seasonal incidence of adult ticks (Acarina: Ixodidae) on cattle in the northern Transvaal. Onderstepoort Journal of Veterinary Research, 46:31-39.

MACLEAN, G.L. (Ed.) 1993. Roberts' Birds of Southern Africa. Cape Town: The Trustees of the John Voelcker Bird Book Fund.

NORVAL, R.A.I. 1975. Studies on the ecology of Amblyomma marmoreum Koch 1844 (Acarina: Ixodidae). Journal of Parasitology, 61:737-742.

NORVAL, R.A.I. 1982. The ticks of Zimbabwe. IV. The genus Hyalomma. Zimbabwe Veterinary Journal, 13:2-10.

NORVAL, R.A.I. 1984. The ticks of Zimbabwe. IX. Haemaphysalis leachi and Haemaphysalis spinulosa. Zimbabwe Veterinary Journal, 15:9-17.

RECHAV, Y., ZEEDERBERG, M.E. \& ZELLER, D.A. 1987. Dynamics of African tick (Acari: Ixodoidea) populations in a natural Crimean-Congo hemorrhagic fever focus. Journal of Medical Entomology, 24:575-583.

SPICKETT, A.M., HORAK, I.G., VAN NIEKERK, ANDREA \& BRAACK, L.E.O. 1992. The effect of veld-burning on the seasonal abundance of free-living ixodid ticks as determined by drag-sampling. Onderstepoort Journal of Veterinary Research, 59:285-292.

SWANEPOEL, R. \& BURT, F.J. 2004. Crimean-Congo haemorrhagic fever, in Infectious diseases of livestock edited by J.A.W. Coetzer \& R.C. Tustin. Cape Town: Oxford University Press Southern Africa: 1077-1085.

THEILER, GERTRUD 1962. The Ixodoidea parasites of vertebrates in Africa south of the Sahara (Ethiopian region). Project S 9958. Report to the Director of Veterinary Services, Onderstepoort. Mimeographed.

UYS, A.C. \& HORAK, I.G. 2005. Ticks on crested francolins, Francolinus sephaena and on the vegetation on a farm in Limpopo Province, South Africa. Onderstepoort Journal of Veterinary Research, 72:339-343.

WALKER, JANE B. 1991. A review of the ixodid ticks (Acari, Ixodidae) occurring in southern Africa. Onderstepoort Journal of Veterinary Research, 58:81-105.

WALKER, JANE B., KEIRANS, J.E. \& HORAK, I.G. 2000. The genus Rhipicephalus (Acari, Ixodidae): a guide to the brown ticks of the world. Cambridge: Cambridge Academic Press.

ZELLER, H.G., CORNET, J.P. \& CAMICAS, J.L. 1994. Experimental transmission of Crimean-Congo haemorrhagic fever virus by West African ground-feeding birds to Hyalomma marginatum rufipes ticks. American Journal of Tropical Medicine and Hygiene, 50:676-681. 